\title{
Evaluation of the Marriage Registration Office of Religious Affairs at Makassar City
}

\author{
Muhammadong \\ Faculty of Sport Science \\ Universitas Negeri Makassar \\ Makassar, South Sulawesi, Indonesia \\ muhammadongunm@yahoo.co.id
}

\author{
Rifdan \\ Faculty of Social Science \\ Universitas Negeri Makassar \\ Makassar, South Sulawesi, Indonesia
}

\author{
Syarifah Balkis \\ Faculty of Social Science \\ Universitas Negeri Makassar \\ Makassar, South Sulawesi, Indonesia
}

\begin{abstract}
The purpose of this study was to evaluate the marriages registration at the Religious Affairs Makassar Office. This research was conducted at the office of religious affairs Wajo District of Makassar. The type used is qualitatively by describing the circumstances that occurred in the Office of Religious Affairs at the time of registration of marriages. The results showed that there should be an evaluation at the marriage registration office of the District Religious Affairs Wajo Makassar. This indicates there are $\mathbf{1 0}$ determination of marriage or ask for marriage is set each year are filed by citizens to the Religious Affairs Office of the District Wajo. Nevertheless, the events of marriage in the District Wajo Makassar City is very encouraging.
\end{abstract}

Keywords: evaluation, records, marriage

\section{INTRODUCTION}

Mahmood the aim of marriage is to create harmony of the family [1]. The Qur'anic ideals can be achieved and couples to produce offspring in the household. The aim of marriage is not just a lasciviousness, because humans are dignified in the face of the livelihoods, but the purpose of marriage is to nurture the desire to love each other and love each other, as God commands and instructions of the Prophet. It is stated in the Qur'an Surah Al-Rum: 30/21 "And among the signs of His power is that He created for you wives of your kind alone, that you tend to be and feel at ease to him and made him among you a sense of love and affection. Verily in this is truly there are signs for a people who think [2].

Cammack stated that the enactment of Act of the Republic of Indonesia Number 1 Year 1974 on Marriage expected realization of order marriages in Indonesia, especially the problem of recording [3]. This needs to be set up for the harmony of a householder's life, in addition to providing legal certainty to all parties, especially the husband, wife, and children and heirs.

The purpose of registration of marriage is to realize the administrative conduct marriages in the community in addition to ensure the enforcement of the rights and obligations of husband and wife [4]. This is a political law of the state of a preventive nature to coordinate society for the establishment of law and order in living systems, including the marital problems that are believed not escape from a variety of irregularities and disputes between husband and wife. Because of the involvement of authorities/state in regulating marriage in the form of record keeping is a must.

The number of marriages that are not listed will open the gap a practice of polygamy among the people even a little done by the officials or educated. Moreover, structuring registration of marriage is needed in order to avoid the practice of polygamy and the most important thing in order to get recognition from the state.

The amount of practice polygamy or marriage without state recognition (nikah Sirri) that occurred in Makassar due to the recording system that is not too tight. So necessary to evaluate the system of registration of marriages so that people do care and are not playing the name of marriage.

Makassar city has high category of people who did events marriage. However, there is little merriage event is not recorded in the Office of Religious Affairs (KUA) or marriages conducted under the hand called Sirri thrives in Makassar. one of the causes of marriage without state recognition (nikah sirri) occurred in Makassar due to lack of public awareness about the registration of marriages.

Of the work is done, the District Wajo Kota Makassar is one of the districts that need to be evaluated registration of marriages because of as every year the citizens submitted a proposal to the Office of Religious Affairs (KUA) to request the institution of marriage which held its commencement will be conducted by the Religious Courts. This indicates that the institution of marriage the Office of Religious Affairs (KUA), or allow their officers negligence registration of marriage. Therefore, marriage is not recorded in the Office of Religious Affairs (KUA). Thus, there should be an evaluation of the system of registration of marriages. So that marriage can be a formal legality in the state system.

\section{RESEARCH METHOD}

The kind of research can be categorized as a descriptive study with qualitative approach for the problem under study is phenomenological. In this case do the analysis on the evaluation of registration of marriages. In order to determine listed or not listed marriages held in the Religious Affairs Office districts Wajo Makassar. 
The approach used is multi-disciplinary, namely; 1. normative theological approach, this approach was used to analyze a marriage issue on the basis of the Koran, the Hadith, and ijtihad. 2. juridical approach, this approach was used to determine the legal issues arising in matters of marriage and recordation. 3. Administrative approach, this approach was used to determine the system of registration of marriages. Being the instrument used in this study that the data obtained is more directional, it made research activity schedule shows the allocation of time, place of execution, and conducting interviews, direct recording, in order to provide guidance so it can focus on the study material. And data collection techniques which transactions are carried out is observation or direct observation by the Office of Religious Affairs Wajo Makassar District of the civil registry system.

\section{RESULTS AND DISCUSSION}

\section{A. Results}

The results of the research that has been conducted in the District Wajo about marriage documentation evaluation that indicates the data is based on Islamic Guidance in Figures (BIDA10) religious Affairs office (KUA) district Wajo that marriage rates showed an increase of at least 314 events each year of marriage, so that on average the number of marriages in the range above 15 events marriage every month. This figure is very significant gains, where the majority of its people are not Muslims.

Nevertheless, there is still a marriage event that is not recorded. From the figures obtained show that people do isbat Wajo District of wedlock each year no less than 10 events. This shows that there is a wedding or a civil registry office outside the religious Affairs office (KUA) District Wajo. So it becomes the input to the government, in this case the Ministry of Religious of Makassar to be more careful against the registration of marriages.

The document distribution and the use of a marriage certificate shows that the consumption levels of the marriage book can not be met each year. This was evidenced by the absence of a broken marriage book and marriage certificate distribution level above the average rat 34 each month and if you add up the total annual figures show 272 marriage book. However, the remaining unused marriage book still is around 166 digits each year that should be returned to the state. So it is still possible opening of opportunities for using the marriage book is done outside the religious Affairs office (KUA).

Based on data from the events of marriage oriented place, trustee, age, and marital status through document Islamic Guidance in Figures (BIDA 11) indicates that marriage performed in KUA numbered from 0 events, while marriages performed in the building amounted to as much as 16 and marriage done at home amounted to as much as 231. As for marriages performed by trustee nasab amount to as much as 234, as many as 0 Adel, Adel as many as 13 others.

The marriage that is based on the age of marriage, then found as for men under age 19, the range of numbers from 0 people, being over the age of $19-25$, as many as 25 people, was over the age of 25 years as many as 172 people. The wedding is done by women based on data from Islamic Guidance in Figures (BIDA 11) shows that the age of 16 and under from 0 people, over 16-20 years as many as 42 people, were over 20 years old (adult) as many as 205 people.

As for marriage based on marital status, it can be stated as for male virgins as many as 205 people, male widowers were 42 people while the practice of polygamy as 0 (none). While marriages performed by female girl 196 people, widows were 51 people, while polygamy from 0 vote (no).

\section{B. Discussion}

The discussion of this study that the registration of marriage must go through the procedure so that no one in doing marriage without both parties recording it. As for the marriage registration procedure includes several stages, namely; (a) Preparation. At this stage Employee Assistant Registrar of Marriage (PPN) providing advice and guidance to encourage the community in planning marriage should make preparations.

(b) Notification Level. After a preliminary preparation for mature people who want to get married then let his will to assistant Marriage Registrar Officer (PPN) that regionalization place the ceremony live, at least ten working days before the ceremony was held. (c) The Marriage Checkup. At this stage, the prospective husband, candidates and representatives wife marriage should be done together, but there is no hindrance if the examination is carried out separately.

In fact, in a state of doubt, it should be examined individually. (d) Phase Announcement Will marriage. At this stage, Assistant Registrar of Marriage Employees (PPN) will announce the marriage on a bulletin board (model NC) after the requirements fulfilled. Announcements installed in places that are easy on the public know. (e) Level Engagement and recordation.

After the expiry of the announcement, the ceremony marriage overseen by the supervision and in the presence of Assistant Registrar Official Marriage (PPN) then recorded in the sheet (Model NB) pages 4 and signed by the husband, wife, guardians and witnesses as well as Assistant Registrar Official Marriage (PPN) watching no later than 15 days after the marriage ceremony. (f) Phase Rejection Will marriage.

At this stage, if not met the requirements determined both requirements under the law of marriage and the requirement under the legislation in force, the Assistant Registrar of Marriage Employees (PPN) must resist the implementation marriage, by providing a letter of denial to the person concerned to affirm the reason the reason for disapproval (N9 model form).

\section{CONCLUSION}

Marriage is the laws that Allah commanded to his servant for humans to live happily and gave birth to offspring. Only in 
running the family boat, sometimes does not run smoothly even many challenges facing.

However, the marriage took administrative process that does little people sometimes break. So look for shortcuts by not going through the stages of administration. The marriage registration is needed so that husband and wife get recognition from the government and the offspring are born earn legality before the law.

From the research results presented show that the rate of marriages in the District Wajo Makassar City showed a number of very significant and encouraging. This was evidenced by the enthusiasm of people to want noted marriage in the Office of Religious Affairs of Makassar. Nevertheless, there is still a marriage that is not recorded. Not because of the administration, but because of the ignorance of the public about the registration of marriages. So that the Office of Religious Affairs Wajo District of receiving the institution of marriage or the public request for legalized marriage.

When the registration of marriages transactions are carried out properly, then the purpose of the implementation of good governance will also be run in accordance aspired. So that no other parties are taking advantage causing marital easily infringed by certain elements. Then the principles set out in good governance: transparency, accountability, effectiveness, and efficiency of the implementation of the system of registration of marriages.

\section{REFERENCES}

[1] T. Mahmood, Family law reform in the Muslim world. Indian Law Institute, New Delhi, 2015.

[2] Departemen Agama RI, Al-Qur'an dan Terjemahannya. Jakarta: Direktorat Jenderal Bimbingan Masyarakat dan Penyelenggaraan Haji, 2006.

[3] M. Cammack, 'Islamic Law in Indonesia's New Order', Int. Comp. Law $Q$. , vol. 38, no. 1, pp. 53-73, 1989.

[4] S. Butt, 'Polygamy and mixed marriage in Indonesia: Islam and the marriage law in the courts', 2009. 